\title{
Free radical scavenging potential and antibacterial activity of Cola nitida and Garcinia kola extracts against bacterial strains isolated from patients with urinary tract infections
}

\author{
I.V. Anyiam ${ }^{1 *}$ and P.P.E. Mounmbegna ${ }^{2}$ \\ ${ }^{I}$ Department of Microbiology, Faculty of Science, Federal University Otuoke, Bayelsa State, Nigeria \\ ${ }^{2}$ Department of Biochemistry, Faculty of Science, Madonna University Nigeria, Elele, Rivers State, \\ Nigeria \\ Correspondence: ifetgod@yahoo.co.uk; (iD https://orcid.org/0000-0002-3705-3988
}

Received: $23^{\text {rd }}$ May 2019, Revised: $16^{\text {th }}$ July 2020, Accepted: $2^{\text {th }}$ November 2020

\begin{abstract}
Cola nitida and Garcinia kola are found and widely consumed in West Africa. The seeds of these plants have various traditional uses and are reported to exhibit several bioactivities. Their phytochemical, antioxidant and antibacterial properties of methanol, ethanol and aqueous extracts were investigated in the present study. Phytochemical screening and quantification of total phenolic contents analysis were carried out for phytochemical investigation. Preliminary phytochemical screening revealed the presence of flavonoids, alkaloids, tannins, saponins, protein and glycosides in the seed extracts. Quantitative phytochemical constituents revealed $0.818 \pm 0.021$ and $0.700 \pm 0.017 \mathrm{mg}$ of phenolic compounds and total flavonoid content of $25.63 \pm 1.60$ and $25.10 \pm 1.85 \mathrm{mg}$ in $G$. kola and $C$. nitida respectively. The extracts showed potent antioxidant activities compared to standard antioxidants by significantly inhibiting 2, 2-diphenyl-1picrylhydrazyl (DPPH), hydroxyl radical $(\cdot \mathrm{OH})$, and superoxide anion radicals $\left(\mathrm{O}_{2} \cdot\right)$ dose dependently. The methanol extracts of $G$. kola and $C$. nitida showed significant inhibitory action $(\mathrm{p}<0.05)$ against the bacterial isolates. The minimum inhibitory concentration obtained for methanol extract of the plants and both the mixture was $12 \mathrm{~mm}$ at $31.25 \mathrm{mg} / \mathrm{ml}$ for Klebsiella pneumoniae while the ethanol and aqueous extract of the plants and both the mixture was $13 \mathrm{~mm}$ and $12.33 \mathrm{~mm}$ at $31.25 \mathrm{mg} / \mathrm{ml}$ and $125 \mathrm{mg} / \mathrm{ml}$ respectively for E. coli. A direct correlation was observed between total phenolic content of extracts and radical scavenging potential, thus linking the observed bioactivities of these extracts to the presence of the phytochemical. The mixture of these seed extracts showed greater effect against the bacterial isolates, therefore providing a platform for advance studies in the development of drugs against infectious diseases.
\end{abstract}

Key words: Agar well dilution, antibacterial activity, Cola nitida, Garcinia kola, Free radical scavenging potential

\section{Introduction}

The alarming rate of antimicrobial drug resistance by pathogenic microorganisms against synthetic antibiotics (Maiyo et al. 2010) is a serious global problem. Indeed, the emergence of bacterial resistance to antibacterial drug today has become a common 
phenomenon, and consequently, antibiotic resistance has imposed both a biological and economic cost (Chabot et al. 2002, Chen et al. 2002, Chessin et al. 2005). The rate of antimicrobial resistance has prompted the search for new plants with antimicrobial properties and potentials to serve as sources of raw material for the synthesis of new drugs (Akoachere et al. 2002).

Traditional healers use different plant medicines to provide health care to most of the people in a curative rather than a preventive approach in the developing countries for common ailments (Gabriel et al. 2007). The availability and economy of these plants as direct therapeutic agents makes it more attractive when compared to modern medicine (Agbo and Ngogang 2005, Agbo et al. 2005). Natural plants contain phytochemical properties similar to synthetic antibiotics and have been used in folk medicine to treat infections (Ezeigbo 2016). In addition, people with different cultural backgrounds from ancient times to the present day have used herbal medicines (ElMahmood et al. 2008) to cure infections. Hence, plants continue to be the most preferred exclusive source of drugs for the majority of the world's population (Fabiola et al. 2003, Jonathan and Fasidi 2003, Ajayi et al. 2008). According to WHO (2000), "medicinal plants when administered to man or animals exert a sort of pharmacological action on them". For this reason, medicinal plants are used as sources to produce useful drugs utilized by people worldwide for treatment of infectious diseases.

Infectious diseases are the major causes of death accounting for approximately one half of all deaths in tropical countries (Iwu et al. 2009). In recent times, medicinal plants continue to play a major role in primary healthcare as therapeutic remedies in many developing countries (Jonathan and Fasidi 2003, 2005, Jonathan et al. 2007) as some plants have been found to be rich in secondary metabolites, such as tannins, terpenoids, alkaloids, flavonoids, phenols, steroids and volatile oil. These compounds are said to be responsible for their therapeutic activities (Rabe and Vanstoden 2000, Cowan 2009). Furthermore, plants can serve as a reservoir of effective chemotherapeutic agent which provides valuable natural drug for effective and efficient management of human and plant diseases (Kanomal et al. 2014).

In Nigeria, studies have been carried out on a variety of these medicinal plants yet a good number of them with putative medicinal and antimicrobial potentials are yet to be studied (Amalu et al. 2014). Among these plants are Garcinia kola and Cola nitida whose medicinal uses may have not been fully explored in the treatment of bacterial infections, especially, urinary tract infections. These medicinal properties could occur in different forms varying from biological, synthetic chemotherapeutic, antibiotics, and phytotherapeutic agents (Arekemase et al. 2012). The action of these agents could either be 'bactericidal' or 'bacteriostatic' (Arekemase et al. 2012). The importance and quest for these medicinal plants origin that could be of potential benefit as antibacterial agents stimulated the interest in Garcinia kola ('bitter kola') and cola nitida (kola nut) seeds which are widely consumed as stimulant (Atawodi et al. 2005).

Garcinia kola, also generally known as 'Bitter kola' is a flowering plant species that belongs to the family of tropical plants known as Guttiferae or Clusiaceae (Adesuyi et al. 2012). In Nigerian languages, it is commonly called "Namijin Goro" in Hausa, "Orogbo" in Yoruba, and "Agbilu" in Igbo (Dalziel 2008). Bitter kola is also 
known as African wonder nut because almost every part of it has been found to be of medicinal importance (Adegboye et al. 2008).

Cola nitida (Kola nut) ("Goro" in Hausa; "Obi gbanja" in Yoruba; "Oji" in Igbo, Keay et al. 2014) is a member of the family Steculicca. It is a tree plant found in Sierra Leone, North Ashanti, tropical Western Africa, West Indies, Brazil and Java (Grieve, 2001). Cola nitida was originally distributed along the west coast of Africa from Sierra Leone to the Republic of Benin with the highest frequency and variability occurring in the forest areas of Côte d'Ivoire and Ghana (Opeke 2012). In addition, kola nut is a native stimulant which commonly chewed in many West African cultures (Opeke 2012). In Nigeria, it is often used in traditional occasions, to welcome guest and receive visitors at home.

More so, the need for new antimicrobial agents is closely related with the problem of emergence of resistant strains to most antibiotics. Hence, this study was conducted to determine the phytochemical constituents, free radical scavenging potential and antibacterial activity of Cola nitida and Garcinia kola.

\section{Materials and Methods}

\subsection{Isolation and Identification}

Sixty urine samples were collected one each from female patients attending Federal Medical Centre, Yenagoa, from the period of May to July in 2017. Females were used because they were the available patients at the time of the study and are considered to be more predisposed to urinary tract infections. The specimens were cultured on MacConkey agar, Blood agar and CLED (Cystine lactose electrolyte deficient) agar plates using the streak method. Different agar was used to selectively identify and differentiate the possible bacteria including the fastidious organism that might be present in the culture specimen. Plates were inoculated and incubated at $37^{\circ} \mathrm{C}$ for 24 hours. The isolates were identified using Gram staining technique and Biochemical tests which include catalase, urease, coagulase, oxidase, and indole.

\subsection{Collection and authentication of plant material}

Dried seeds of Garcinia kola (bitter kola) and Cola nitida (kola nut) were procured from a local herb dealer at Swali market in Yenagoa Local Government Area, Bayelsa State, Nigeria. They were authenticated with voucher specimen number MP-182 and MP-183 in the Pharmacognosy Department, Madonna University, Nigeria, Elele, Rivers State, Nigeria.

\subsection{Processing and extraction}

The seeds of Garcinia kola and Cola nitida were peeled, thoroughly washed and rinsed in distilled water, and both were sliced into tiny pieces with the use of a clean stainless 
steel knife, then air-dried at room temperature for 4 weeks, and pulverized using laboratory mortar and pestle. Different organic solvents (methanol, ethanol and aqueous) were used for the extraction of these plants as described by Alade and Irobi (1993). Fifty grams (50 g) of each seed powder was dispensed into a cotton wool stock thimble chamber of the soxhlet apparatus and $500 \mathrm{ml}$ of methanol was dispensed into flat bottom flask. The extraction solvents were heated in the bottom flask, vaporized into the thimble, condensed in the condenser and dripped back. When the liquid content reached the siphon arm, the liquid contents was emptied into the bottom flask again and the process was continued until the absorbent was clear. The extracts obtained were completely evaporated (Green 2004) and stored in the refrigerator at $4^{\circ} \mathrm{C}$ until use. The percentage (\%) yields of the dry residue were calculated (Pudhom et al. 2007). The same procedure was repeated successfully for ethanol and aqueous extracts. Extracts were then dissolved in the appropriate solvent for the phytochemical and antibacterial assay.

\subsection{Phytochemical screening}

Phytochemical screening was done using qualitative and quantitative phytochemical analysis. Qualitative analysis involved tests for flavonoids, tannins, carbohydrates, glycosides, saponins, resins, terpenoids and alkaloids. These were carried out using standard methods (Harborne 1984, Sofowora 1993, Trease and Evans 2001).

Quantitative Analysis determined the total phenols, tannin, total flavonoids and total anthocyanin contents. The total phenolics were determined using Folin-Ciocalteau reagent (FCR) as described by Velioglu et al. (1998) with slight modifications. Tannin content in each sample was determined using insoluble polyvinyl-polypirrolidone (PVPP), which binds tannins as described by Makkar et al. (1993). The flavonoids content was determined according to the method described by Kumaran and Karunakaran (2006) with slight modifications. This method was based on the formation of a flavonoid-aluminum complex, which absorbs maximally at $415 \mathrm{~nm}$. The total anthocyanin contents of the plant extracts were measured using a spectrophotometric $\mathrm{pH}$ differential protocol described by Giusti and Wrolstad (2001) and Wolfe et al. (2003) with slight modifications.

\subsection{In vitro Antioxidant Assays}

\section{Quantitative DPPH radical-scavenging assay}

The hydrogen atoms or electrons donation ability of the corresponding extract was measured from the bleaching of purple coloured methanol solution of DPPH. The scavenging activity on DPPH free radicals by the extract was assessed according to the method reported by Gyamfi et al. (1999) with slight modifications. 
Hydroxyl radical ( $\cdot \mathrm{OH})$-scavenging assay

The 2-deoxyribose assay was used to determine the scavenging effect of the extract on the hydroxyl $(\cdot \mathrm{OH})$ radical, as reported by Halliwell et al. (1987) with minor modifications.

\section{Superoxide Radical $\left(\mathrm{O}_{2^{*}}\right)$ Scavenging Assay}

This assay was based on the capacity of the extract to inhibit the photochemical reduction of nitro blue tetrazolium (NBT) (Beauchamp and Fridovich 1971) and the method used by Martinez et al. (2001) to determine superoxide dismutase with slight modifications.

\subsection{Reconstitution of plant extract}

For preliminary screening of antibacterial activity of the plant extracts against bacteria isolated, all the dried extracts were dissolved in dimethyl sulfoxide (DMSO) to a final stock concentration of $2.5 \% \mathrm{w} / \mathrm{v}$. As DMSO has been shown not to have any inhibitory effect on the growth of microorganisms (Zgoda and Porter 2001, Kuete et al. 2008), it was used as the negative control for all the experiments. A two-fold serial dilution was also undertaken to obtain lower concentration ranges in sterile test tubes.

\subsection{Antibacterial Aassay}

Preparation of 0.5 Mcfarland turbidity standards was done as described in NCCLS (NCCLS 2010). The agar well diffusion method was done following Atata (2003). An overnight agar-culture of each bacterial isolate was made, and the suspension of microorganisms was made in sterile normal saline and adjusted to 0.5 McFarland standards $\left(10^{8} \mathrm{CFU} / \mathrm{ml}\right)$ (NCCLS 2010). From the stock of $500 \mathrm{mg} / \mathrm{ml}$ extract, twofold serial dilutions were made to $250,125,62.5$, and $31.25 \mathrm{mg} / \mathrm{ml}$. Each labeled Mueller Hinton agar plate was uniformly inoculated with a test organism by using a sterile cotton swab rolled in the suspension to streak the plate surface in a form that lawn growth could be observed. A sterile cork borer of $6 \mathrm{~mm}$ diameter was used to make 5 wells on the medium in each plate. Before boring of the well in agar, the cork borer was sterilized by dipping in alcohol and flaming. $50 \mu \mathrm{l}$ of the 5 different extract concentrations were dropped into each well using a micropipette. All antibacterial assays were performed on duplicate plates. The underside of each well was appropriately labeled. Other solvents used for extraction apart from water were tested for each organism. The inoculated plates were kept in the refrigerator for 1 hour to allow the extracts to diffuse into the agar (Atata et al. 2003). The plates were incubated upright at $37^{\circ} \mathrm{C}$ for 24 hours. After incubation, the diameters of the zones of inhibitions obtained were measured, using a pair of calipers and meter ruler. The measurement was done at the back of the plate. The diameter was measured from one end of the zone to the other. Where the zone of inhibition is not perfectly circular, the average of the long and short axis was used. The diameter of the zone of inhibition was obtained for 
the two plates having the same concentration of the extract against a particular microorganism, and the average was used. For positive control, $30 \mu \mathrm{l}$ of $40 \mathrm{mg} / \mathrm{ml}$ of gentamycin was used while $50 \mu 1$ of $2.5 \%$ DMSO was used as negative control.

\subsection{Determination of minimum inhibitory concentration}

The minimal inhibitory concentrations (MICs) of the extracts on the bacterial isolates were determined by macro broth dilution techniques following the recommendation of the Clinical and Laboratory Standard Institute (CLSI 2015).

One gram of the extract was dissolved in $1 \mathrm{ml}$ of $20 \%$ DMSO to get an extract concentration of $250 \mathrm{mg} / \mathrm{ml}$. Various serial dilutions were made from this stock solution in tubes of $1 \mathrm{ml}$ sterile Mueller Hinton broths to get $125 \mathrm{mg} / \mathrm{ml}, 62.5 \mathrm{mg} / \mathrm{ml}$, and $31.25 \mathrm{mg} / \mathrm{ml}$. An overnight nutrient broth culture of the test bacterial isolate was standardized to 0.5 McFarland turbidity standards. Different dilutions of the suspension were made in a sterile normal saline to obtain a final inoculum concentration of $106 \mathrm{CFU} / \mathrm{ml}$. Then $1 \mathrm{ml}$ of this adjusted inoculum was added to each tube of the Mueller Hinton broth containing different concentration of the crude extract. Each tube was mixed and incubated at $37^{\circ} \mathrm{C}$ for 24 hours (Nweze and Onyishi 2010). This experiment was conducted in duplicate for all the bacterial isolates. A tube of Mueller Hinton broth containing only the $1 \mathrm{ml}$ suspension of the isolate without extract and the tubes of Mueller Hinton broth containing different concentrations of the extract without the isolate were used as controls. The tubes were examined after 24 hrs incubation. The MIC of the extract was taken as the lowest extract concentration that completely inhibited the growth of the bacterial isolates in the tubes, as indicated by lack of visual turbidity.

\subsection{Determination of the use of mixtures of the extract}

This was done by measuring equal volume of each of extract type (ethanol, methanol and aqueous) of the plants seeds and then mixed. 50 $\mu 1$ of each mixture was put into each well as in the antibacterial bioassay section to test the sensitivity potentials. This was done in triplicates.

\subsection{Statistical analysis}

All experiments were done in triplicate and the data thus obtained were reported as mean \pm standard error of mean. Statistical analysis was carried out to determine whether there was significant difference among the inhibitory actions of Garcinia kola and Cola nitida alone and in mixtures of extracts using Analysis of Variance and Bonferroni post-test at 95\% confidence level using Graph Pad PRISM Version 5.01 (Chao-Hsun et al. 2010). 


\section{Results}

Total of 48 isolates were obtained from the 60 specimens collected from patients with urinary tract infections (UTI) attending Federal Medical Centre. Bacterial species isolated include Proteus vulgaris, Escherichia coli, Staphylococcus aureus, Pseudomonas aeruginosa and Klebsiella pneumoniae. Table 1 shows the frequency distribution of bacterial isolates from patients with UTI. Escherichia coli had the highest occurrence (29.17\%) while Proteus vulgaris had the lowest occurrence $(8.33 \%)$.

Table 1: Frequency distribution of bacterial isolates (48) from patients with urinary tract infections.

\begin{tabular}{lcc}
\hline Organisms & Number of isolates & Percentage occurrence \\
\hline Proteus vulgaris & 4 & 8.33 \\
Escherichia coli & 14 & 29.17 \\
Staphylococcus aureus & 12 & 25.00 \\
Pseudomonas aeruginosa & 8 & 16.67 \\
Klebsiella pneumoniae & 10 & 20.83 \\
\hline
\end{tabular}

Table 2 shows the zone of inhibition of the positive control (gentamycin) used against bacterial isolates. The zones of inhibition produced by the positive control were larger than the zones produced by the plant extracts.

Table 2: Zones of Inhibition ( $\mathrm{mm}$ ) of Gentamycin (positive control) against bacterial isolates.

\begin{tabular}{lcc}
\hline Organisms & Concentration $(\mu 1)$ & ${\text { Zone of inhibition }(\mathrm{mm}) \text { Gentamycin }{ }^{\text {a }}}$ \\
\hline Proteus vulgaris & 30.0 & 28.00 \\
Escherichia coli & 30.0 & 26.00 \\
Staphylococcus aureus & 30.0 & 18.00 \\
Pseudomonas aeruginosa & 30.0 & 26.00 \\
Klebsiella pneumoniae & 30.0 & 29.00 \\
\hline
\end{tabular}

${ }^{a}$ Values are mean inhibition zone $(\mathrm{mm})$ from three replicates

The methanol extracts of $G$. kola, $C$. nitida and the mixture of extracts showed antibacterial activity against all the bacterial isolates at a concentration of $500 \mathrm{mg} / \mathrm{ml}$, with G. kola having the largest zone of inhibition of $23 \mathrm{~mm}$ against $E$. coli and Klebsiella pneumoniae respectively. C. nitida showed activity against Klebsiella pneumoniae with largest zone of inhibition of $21.33 \mathrm{~mm}$ while the mixture of both extracts showed activity against $P$. vulgaris and $E$. coli with the zone of inhibition of $25.66 \mathrm{~mm}$ respectively $(\mathrm{p}<0.05)$ as shown in Table 3. 
Table 3: Mean zone of Inhibition (mm) of Methanol extract of Garcinia kola, Cola nitida and mixture of extracts against bacterial isolates.

\begin{tabular}{|c|c|c|c|c|c|c|}
\hline \multirow{2}{*}{ Bacterial isolate } & \multirow{2}{*}{ Plant extract } & \multicolumn{5}{|c|}{ Concentration } \\
\hline & & $500 \mathrm{mg} / \mathrm{ml}$ & $250 \mathrm{mg} / \mathrm{ml}$ & $125 \mathrm{mg} / \mathrm{ml}$ & $62.5 \mathrm{mg} / \mathrm{ml}$ & $31.5 \mathrm{mg} / \mathrm{ml}$ \\
\hline \multirow[t]{3}{*}{ Proteus vulgaris } & Garcinia kola & $21.33 \pm 0.88^{\mathrm{A}}$ & $20.00 \pm 1.15^{\mathrm{D}}$ & $17.33 \pm 0.67^{\mathrm{G}}$ & $13.00 \pm 0.58^{\mathrm{J}}$ & NI \\
\hline & Cola nitida & $17.33 \pm 0.33^{\mathrm{B}}$ & $16.00 \pm 0.58^{\mathrm{E}}$ & $13.66 \pm 0.33^{\mathrm{H}}$ & $11.33 \pm 0.33^{\mathrm{J}}$ & NI \\
\hline & Mixture of extracts & $25.66 \pm 0.33^{\mathrm{C}}$ & $22.33 \pm 0.33^{\mathrm{F}}$ & $20.00 \pm 0.58^{\mathrm{I}}$ & $16.66 \pm 0.33^{\mathrm{K}}$ & $14.33 \pm 0.33^{\mathrm{L}}$ \\
\hline \multirow[t]{3}{*}{ Escherichia coli } & Garcinia kola & $23.00 \pm 0.58^{\mathrm{A}}$ & $21.66 \pm 0.88^{\mathrm{D}}$ & $19.66 \pm 0.33^{\mathrm{G}}$ & $17.00 \pm 0.58^{\mathrm{J}}$ & $14.66 \pm 0.33^{\mathrm{M}}$ \\
\hline & Cola nitida & $19.00 \pm 0.58^{\mathrm{B}}$ & $16.00 \pm 0.58^{\mathrm{E}}$ & $14.00 \pm 0.58^{\mathrm{H}}$ & $12.33 \pm 1.20^{\mathrm{K}}$ & $0.00 \pm 0.00^{\mathrm{N}}$ \\
\hline & Mixture of extracts & $25.66 \pm 0.33^{\mathrm{C}}$ & $21.33 \pm 0.33^{\mathrm{D}}$ & $18.33 \pm 0.33^{\mathrm{G}}$ & $15.00 \pm 0.58^{\mathrm{J}}$ & $13.33 \pm 0.33^{\mathrm{M}}$ \\
\hline \multirow[t]{3}{*}{ Staphylococcus aureus } & Garcinia kola & $17.66 \pm 0.33^{\mathrm{A}}$ & $16.00 \pm 0.58^{\mathrm{CD}}$ & $14.66 \pm 1.20^{\mathrm{E}}$ & NI & NI \\
\hline & Cola nitida & $17.66 \pm 0.88^{\mathrm{A}}$ & $15.66 \pm 0.33^{\mathrm{C}}$ & $0.00 \pm 0.00^{\mathrm{F}}$ & NI & NI \\
\hline & Mixture of extracts & $20.00 \pm 0.58^{\mathrm{B}}$ & $17.66 \pm 0.33^{\mathrm{D}}$ & $15.66 \pm 0.33^{\mathrm{E}}$ & NI & NI \\
\hline \multirow[t]{3}{*}{ Pseudomonas aeruginosa } & Garcinia kola & $15.66 \pm 0.33^{\mathrm{A}}$ & $13.00 \pm 0.58^{\mathrm{C}}$ & $0.00 \pm 0.00^{\mathrm{E}}$ & NI & NI \\
\hline & Cola nitida & $16.33 \pm 0.67^{\mathrm{A}}$ & $13.66 \pm 0.33^{\mathrm{C}}$ & $0.00 \pm 0.00^{\mathrm{E}}$ & NI & NI \\
\hline & Mixture of extracts & $19.00 \pm 0.58^{\mathrm{B}}$ & $16.00 \pm 0.58^{\mathrm{D}}$ & $10.33 \pm 0.58^{\mathrm{F}}$ & NI & NI \\
\hline \multirow[t]{3}{*}{ Klebsiella pneumoniae } & Garcinia kola & $23.00 \pm 0.58^{\mathrm{AB}}$ & $20.33 \pm 0.33^{\mathrm{C}}$ & $18.33 \pm 0.67^{\mathrm{E}}$ & $14.00 \pm 0.58^{\mathrm{G}}$ & $0.00 \pm 0.00^{\mathrm{H}}$ \\
\hline & Cola nitida & $21.33 \pm 0.33^{\mathrm{A}}$ & $20.00 \pm 0.58^{\mathrm{C}}$ & $18.66 \pm 0.33^{\mathrm{E}}$ & $14.00 \pm 0.58^{\mathrm{G}}$ & $0.00 \pm 0.00^{\mathrm{H}}$ \\
\hline & Mixture of extracts & $25.33 \pm 0.33^{\mathrm{AB}}$ & $22.00 \pm 1.15^{\mathrm{C}}$ & $20.33 \pm 1.20^{\mathrm{E}}$ & $16.33 \pm 0.33^{\mathrm{G}}$ & $12.00 \pm 0.58^{\mathrm{I}}$ \\
\hline
\end{tabular}

Values are given as Mean \pm Standard Error of three replicate plates

$\mathrm{NI}=$ No inhibition

All values of a particular isolate within the same column with shared alphabet superscript are non-significant $(\mathrm{P}>0.05)$. 
Table 4: Mean zone of Inhibition ( $\mathrm{mm}$ ) of Ethanol extract of Garcinia kola, Cola nitida and mixture of extracts against bacterial isolates.

\begin{tabular}{|c|c|c|c|c|c|c|}
\hline \multirow{2}{*}{ Bacterial isolate } & \multirow{2}{*}{ Plant extract } & \multicolumn{5}{|c|}{ Concentration } \\
\hline & & $500 \mathrm{mg} / \mathrm{ml}$ & $250 \mathrm{mg} / \mathrm{ml}$ & $125 \mathrm{mg} / \mathrm{ml}$ & $62.5 \mathrm{mg} / \mathrm{ml}$ & $31.5 \mathrm{mg} / \mathrm{ml}$ \\
\hline \multirow[t]{3}{*}{ Proteus vulgaris } & Garcinia kola & $20.00 \pm 0.58^{\mathrm{A}}$ & $18.00 \pm 0.58^{\mathrm{D}}$ & $15.00 \pm 0.58^{\mathrm{G}}$ & $13.66 \pm 0.33^{\mathrm{J}}$ & NI \\
\hline & Cola nitida & $16.00 \pm 0.58^{\mathrm{B}}$ & $14.33 \pm 0.33^{\mathrm{E}}$ & $12.00 \pm 0.58^{\mathrm{H}}$ & $0.00 \pm 0.00^{\mathrm{K}}$ & NI \\
\hline & Mixture of extracts & $25.33 \pm 0.33^{\mathrm{C}}$ & $22.33 \pm 0.33^{\mathrm{F}}$ & $18.33 \pm 0.88^{\mathrm{I}}$ & $15.33 \pm 0.88^{\mathrm{J}}$ & NI \\
\hline \multirow[t]{3}{*}{ Escherichia coli } & Garcinia kola & $22.66 \pm 0.67^{\mathrm{A}}$ & $20.66 \pm 0.67^{\mathrm{DF}}$ & $18.66 \pm 0.33^{\mathrm{GI}}$ & $16.66 \pm 0.88^{\mathrm{J}}$ & $15.66 \pm 0.33^{\mathrm{M}}$ \\
\hline & Cola nitida & $18.66 \pm 0.67^{\mathrm{B}}$ & $16.00 \pm 0.58^{\mathrm{E}}$ & $14.33 \pm 0.33^{\mathrm{H}}$ & $0.00 \pm 0.00^{\mathrm{K}}$ & $0.00 \pm 0.00^{\mathrm{N}}$ \\
\hline & Mixture of extracts & $25.66 \pm 0.58^{\mathrm{C}}$ & $21.33 \pm 0.67^{\mathrm{F}}$ & $17.33 \pm 0.33^{\mathrm{I}}$ & $15.00 \pm 0.58^{\mathrm{L}}$ & $13.00 \pm 0.58^{\mathrm{O}}$ \\
\hline \multirow[t]{3}{*}{ Staphylococcus aureus } & Garcinia kola & $16.50 \pm 0.33^{\mathrm{A}}$ & $13.66 \pm 0.33^{\mathrm{C}}$ & $0.00 \pm 0.00^{\mathrm{E}}$ & NI & NI \\
\hline & Cola nitida & $17.00 \pm 0.58^{\mathrm{AB}}$ & $15.00 \pm 0.58^{\mathrm{CD}}$ & $13.33 \pm 0.33^{\mathrm{F}}$ & NI & NI \\
\hline & Mixture of extracts & $18.00 \pm 0.58^{\mathrm{B}}$ & $15.66 \pm 0.33^{\mathrm{D}}$ & $13.66 \pm 0.67^{\mathrm{F}}$ & NI & NI \\
\hline \multirow[t]{3}{*}{ Pseudomonas aeruginosa } & Garcinia kola & $15.66 \pm 0.33^{\mathrm{A}}$ & $12.66 \pm 0.33^{\mathrm{D}}$ & $0.00 \pm 0.00^{\mathrm{F}}$ & NI & $\mathrm{NI}$ \\
\hline & Cola nitida & $14.50 \pm 0.33^{\mathrm{A}}$ & $13.83 \pm 1.00^{\mathrm{DE}}$ & $0.00 \pm 0.00^{\mathrm{F}}$ & NI & $\mathrm{NI}$ \\
\hline & Mixture of extracts & $17.33 \pm 0.33^{\mathrm{B}}$ & $15.00 \pm 0.58^{\mathrm{E}}$ & $12.66 \pm 0.33^{\mathrm{G}}$ & NI & NI \\
\hline \multirow[t]{3}{*}{ Klebsiella pneumoniae } & Garcinia kola & $21.33 \pm 0.67^{\mathrm{AB}}$ & $17.33 \pm 0.33^{\mathrm{C}}$ & $15.00 \pm 0.58^{\mathrm{E}}$ & $0.00 \pm 0.00^{\mathrm{G}}$ & $\mathrm{NI}$ \\
\hline & Cola nitida & $19.66 \pm 0.33^{\mathrm{A}}$ & $16.66 \pm 0.88^{\mathrm{C}}$ & $14.00 \pm 0.58^{\mathrm{E}}$ & $0.00 \pm 0.00^{\mathrm{G}}$ & NI \\
\hline & Mixture of extracts & $22.33 \pm 0.33^{\mathrm{B}}$ & $19.66 \pm 0.88^{\mathrm{D}}$ & $17.66 \pm 0.33^{\mathrm{F}}$ & $12.33 \pm 0.33^{\mathrm{H}}$ & NI \\
\hline
\end{tabular}

Values are given as Mean \pm Standard Error of three replicate plates; $\mathrm{NI}=$ No inhibition

All values of a particular isolate within the same column with shared alphabet superscript are non-significant $(\mathrm{P}>0.05)$. 
Ethanol extracts of G. kola, C. nitida and the mixture of extracts showed antibacterial activity against all the bacterial isolates at a concentration of $500 \mathrm{mg} / \mathrm{ml}$. G. kola inhibited the growth of $E$. coli with $22.66 \mathrm{~mm}$ as the largest zone of inhibition while C. nitida showed its highest activity against Klebsiella pneumoniae at zone of inhibition of $19.6 \mathrm{~mm}$. Furthermore, the mixture of extracts showed its effectiveness with the largest zone of inhibition of $25.66 \mathrm{~mm}$ against $E$. coli with significance of (p< 0.05) (Table 4).

Table 5 shows the aqueous extracts of $G$. kola, $C$. nitida and the mixture of extracts against the bacterial isolates. G. kola, $C$. nitida and the mixture of extracts showed antibacterial activity against all the bacterial isolates at a concentration of $500 \mathrm{mg} / \mathrm{ml}$ except against Staphylococcus aureus. The effect of G. kola was seen against $P$. vulgaris with the largest zone of inhibition of $17 \mathrm{~mm}$ while $C$. nitida was able to inhibit the growth of $E$. coli with the largest zone of inhibition of $16.66 \mathrm{~mm}$. The mixture of both extracts equally showed effectiveness against $P$. vulgaris with the largest zone of inhibition of $20 \mathrm{~mm}$ which shows similar results with Omwirhiren et al. (2016).

Table 5: Mean zone of inhibition (mm) of aqueous extract of Garcinia kola, Cola nitida and mixture of extracts against bacterial isolates.

\begin{tabular}{|c|c|c|c|c|}
\hline \multirow{2}{*}{ Bacterial isolate } & \multirow{2}{*}{ Plant extract } & \multicolumn{3}{|c|}{ Concentration* } \\
\hline & & $500 \mathrm{mg} / \mathrm{ml}$ & $250 \mathrm{mg} / \mathrm{ml}$ & $125 \mathrm{mg} / \mathrm{ml}$ \\
\hline \multirow[t]{3}{*}{ Proteus vulgaris } & Garcinia kola & $17.00 \pm 0.58^{\mathrm{A}}$ & $15.33 \pm 0.33^{\mathrm{D}}$ & $12.66 \pm 0.33^{G}$ \\
\hline & Cola nitida & $12.66 \pm 0.88^{\mathrm{B}}$ & $10.66 \pm 0.33^{\mathrm{E}}$ & $0.00 \pm 0.00^{\mathrm{H}}$ \\
\hline & Mixture of extracts & $20.00 \pm 0.58^{\mathrm{C}}$ & $16.00 \pm 0.58^{\mathrm{D}}$ & $13.33 \pm 0.33^{\mathrm{G}}$ \\
\hline \multirow[t]{3}{*}{ Escherichia coli } & Garcinia kola & $15.00 \pm 0.58^{\mathrm{A}}$ & $13.66 \pm 0.33^{\mathrm{C}}$ & $0.00 \pm 0.00^{\mathrm{E}}$ \\
\hline & Cola nitida & $16.66 \pm 1.20^{\mathrm{A}}$ & $14.66 \pm 0.33^{\mathrm{C}}$ & $12.33 \pm 0.33^{\mathrm{F}}$ \\
\hline & Mixture of extracts & $19.00 \pm 1.00^{\mathrm{B}}$ & $14.33 \pm 0.33^{C}$ & $12.66 \pm 0.33^{\mathrm{F}}$ \\
\hline \multirow{3}{*}{$\begin{array}{l}\text { Staphylococcus } \\
\text { aureus }\end{array}$} & Garcinia kola & NI & NI & NI \\
\hline & Cola nitida & NI & NI & NI \\
\hline & Mixture of extracts & NI & NI & NI \\
\hline \multirow{3}{*}{$\begin{array}{c}\text { Pseudomonas } \\
\text { aeruginosa }\end{array}$} & Garcinia kola & $12.33 \pm 0.88^{\mathrm{A}}$ & NI & $\mathrm{NI}$ \\
\hline & Cola nitida & $0.00 \pm 0.00^{\mathrm{B}}$ & NI & NI \\
\hline & Mixture of extracts & $13.00 \pm 0.58^{\mathrm{A}}$ & NI & NI \\
\hline \multirow{3}{*}{$\begin{array}{l}\text { Klebsiella } \\
\text { pneumoniae }\end{array}$} & Garcinia kola & $15.33 \pm 0.67^{\mathrm{A}}$ & $13.00 \pm 0.58^{\mathrm{D}}$ & NI \\
\hline & Cola nitida & $0.00 \pm 0.00^{\mathrm{B}}$ & $0.00 \pm 0.00^{\mathrm{E}}$ & NI \\
\hline & Mixture of extracts & $13.33 \pm 0.33^{\mathrm{C}}$ & $11.66 \pm 0.33^{\mathrm{F}}$ & NI \\
\hline
\end{tabular}

* There was no inhibition detected against any of the bacterial isolates at $62.5 \mathrm{mg} / \mathrm{ml} 31.5 \mathrm{mg} / \mathrm{ml}$ concentrations of the aqueous extracts of single plant species or both plants in mixture, so that those two columns were not shown in the table. Values are given as Mean \pm Standard Error of three replicate plates; NI = No inhibition;

All values of a particular isolate within the same column with shared alphabet superscript are non-significant $(\mathrm{P}>0.05)$.

Table 6 shows the Minimum Inhibitory Concentration (MIC) values for the extracts of G. kola, $C$. nitida and the mixture of extracts against bacteria isolated from UTI. The 
MIC values of the extracts against the isolates were obtained from the agar diffusion assay. The lowest MIC for G. kola, C. nitida and the mixture of extracts were obtained with methanol and ethanol extracts against all bacterial species respectively. However, there was no MIC obtained for S. aureus, P. aeruginosa, and K. pneumonia for aqueous extract, and no MIC obtained for $S$. aureus for aqueous mixture of extracts as well.

Table 6: Minimum Inhibitory Concentration (MIC) values of extract of G. kola, C. nitida and mixture of extracts against bacterial isolates.

\begin{tabular}{lllcl}
\hline \multirow{2}{*}{ Isolate } & \multicolumn{1}{c}{ Plant } & \multicolumn{2}{c}{ Minimum Inhibitory Concentration (mg/ml) } \\
\cline { 3 - 5 } & & Methanol & Ethanol & Aqueous \\
\hline Proteus vulgaris & Garcinia kola & 62.5 & 62.5 & 125 \\
& Cola nitida & 62.5 & 125 & 250 \\
& Mixture of extracts & 31.25 & 62.5 & 125 \\
Escherichia coli & Garcinia kola & 31.25 & 31.25 & 250 \\
& Cola nitida & 62.5 & 125 & 125 \\
\multirow{4}{*}{ Staphylococcus } & Mixture of extracts & 31.25 & 31.25 & 125 \\
aureus & Garcinia kola & 62.5 & 250 & 250 \\
& Cola nitida & 62.5 & 125 & No MIC \\
Pseudomonas & Mixture of extracts & 62.5 & 125 & 500 \\
aeruginosa & Garcinia kola & 250 & 125 & No MIC \\
& Cola nitida & 125 & 125 & 500 \\
Klebsiella & Mixture of extracts & 125 & 62.5 & 250 \\
pneumoniae & Garcinia kola & 62.5 & 62.5 & No MIC \\
& Cola nitida & 31.25 & 62.5 & 250 \\
\hline
\end{tabular}

Qualitative analysis on Garcinia kola and Cola nitida revealed the presence of important phytochemical constituents including phenolic compounds (tannins and flavonoids), saponins and alkaloids as bioactive compounds (Table 7).

Table 7. Qualitative phytochemical constituents of Garcinia kola and Cola nitida extracts.

\begin{tabular}{ccccccccc}
\hline Extract & Flavonoids Tannins & Alkaloids & Terpenoid & Glycoside & Saponins & Resin & Protein \\
\hline G. kola & + & + & ++ & - & + & ++ & - & + \\
C. nitida & ++ & ++ & + & - & + & + & - & + \\
\hline
\end{tabular}

(Key: + Present; ++ Moderately present; +++ Abundant; - Absent)

Quantitative analysis on Garcinia kola and Cola nitida revealed that phenolic compounds were a major class of bioactive components in the extracts Table 8). The amount of total phenolics were $0.818 \pm 0.021 \mathrm{mg}$ and $0.700 \pm 0.017 \mathrm{mg} \mathrm{GAE} / \mathrm{mg}$ of dry plant extracts of $G$. kola and $C$. nitida respectively, whereas the total flavonoid contents were as $25.63 \pm 1.60 \mathrm{mg}$ and $25.10 \pm 1.85$ rutin equivalents / g dry weight plant extract of $G$. kola and C. nitida respectively. 
Table 8: Phytochemical constituents of Garcinia kola and Cola nititda (mean $\pm \mathrm{SD}, \mathrm{n}=3$ ).

\begin{tabular}{lcccccc}
\hline Extract & \multicolumn{3}{c}{ Phenolic contents * } & $\begin{array}{c}\dagger \text { Total } \\
\text { anthocyanin }\end{array}$ & $\begin{array}{c}\text { † Total } \\
\text { flavonols }\end{array}$ & $\begin{array}{c}\text { \$ Total } \\
\text { flavonoids }\end{array}$ \\
\cline { 2 - 4 } & Total Phenols & Non-tannins & Tannins & & \\
\hline G. kola & $0.818 \pm 0.021$ & $0.507 \pm 0.009$ & $0.311 \pm 0.001$ & $4.64 \pm 0.22$ & $9.41 \pm 0.02$ & $25.63 \pm 1.60$ \\
C. nitida & $0.700 \pm 0.017$ & $0.376 \pm 0.001$ & $0.324 \pm 0.007$ & $2.15 \pm 0.22$ & $13.81 \pm 0.92$ & $25.10 \pm 1.85$ \\
\hline
\end{tabular}

* Expressed as mg gallic acid equivalents / mg dry weight plant extract

$\dagger$ Expressed as mg cyanidin 3-glucoside equivalents/100g of dry weight extract

$\star$ Expressed as mg rutin equivalents / g dry weight plant extract

Table 9 shows the concentration of the extracts that inhibited 50\% of the free radicals and lipid peroxidation $\left(\mathrm{IC}_{50}\right)$ which was used to determine the potency of the extracts. The lower the $\mathrm{IC}_{50}$ value the better the extract potency. The plant extracts were efficient inhibitors of different free radicals compared to standard antioxidants. G. kola appears to be more efficient in inhibiting DPPH radical $(9.6 \pm 1.0 \mu \mathrm{g} / \mathrm{ml})$, Superoxide anion $(64.6 \pm 1.5 \mu \mathrm{g} / \mathrm{ml})$ and lipid peroxidation $(282.9 \pm 9.3 \mu \mathrm{g} / \mathrm{ml})$ while $C$. nitida extract is a better inhibitor of Hydroxyl radical $(46.6 \pm 2.5 \mu \mathrm{g} / \mathrm{ml})$.

Table 9: Free radical and lipid peroxidation inhibitory potency $\left(\mathrm{IC}_{50}\right)$ of Garcinia kola and Cola nititda (mean \pm SEM, $\mathrm{n}=3$ ).

\begin{tabular}{|c|c|c|c|c|}
\hline \multirow[b]{2}{*}{ Extract } & \multicolumn{4}{|c|}{ IC 50 value for inhibitory potential $(\mu \mathrm{g} / \mathrm{ml})$} \\
\hline & DPPH radical & $\begin{array}{c}\text { Hydroxyl radical } \\
(\cdot \mathrm{OH})\end{array}$ & $\begin{array}{l}\text { Superoxide anion } \\
\left(\mathrm{O}_{2}{ }^{-{ }^{-}}\right)\end{array}$ & Lipid peroxidation \\
\hline C. nitida & $24.1 \pm 2.1$ & $46.6 \pm 2.5$ & $103.7 \pm 5.2$ & $575.1 \pm 15.4$ \\
\hline G. kola & $9.6 \pm 1.0$ & $99.4 \pm 1.7$ & $64.6 \pm 1.5$ & $282.9 \pm 9.3$ \\
\hline Standard antioxidant & $4.1 \pm 0.3^{*}$ & $38.9 \pm 2.8^{\#}$ & $3.3 \pm 0.2^{\beta}$ & $24.3 \pm 1.4^{£}$ \\
\hline
\end{tabular}

* compared to ascorbic acid; " ${ }^{\#}$ compared to $\alpha$-Tocopherol; ${ }^{\beta}$ compared to rutin;

${ }^{\ddagger}$ compared to butylated hydroxyltoluene

Figure 1 shows the graphical representation of Garcinia kola and Cola nitida extracts which showed significant dose-dependent DPPH radical scavenging capacity. Garcinia kola appears to be more efficient, inhibiting $92.36 \pm 1.31 \%$ of DPPH at a concentration of $125 \mu \mathrm{g} / \mathrm{ml}$ compared to ascorbic acid which inhibited $94.18 \pm 3.22 \%$ at the same concentration.

Figure 2 shows the graphical representation of Garcinia kola and Cola nitida extracts scavenged $\mathrm{OH}$ radical in a concentration dependent manner. The two extracts inhibited 2-deoxyribose degradation above $30 \%$ with maximal inhibition of $76.7 \pm 1.4 \%$ at concentration of $500 \mu \mathrm{g} / \mathrm{ml}$. The scavenging ability of the extracts was significant at all tested concentrations. $C$. nitida extract was found to be powerful quencher of $\mathrm{OH}$ radical thereby preventing the propagation of lipid peroxidation. At high concentrations of both extracts lower activities were observed. 




Fig. 1: Graph comparing DPPH antioxidant activity of different concentrations of ascorbic acid and extracts of Garcinia kola and Cola nitida (values are expressed as mean \pm SEM, n $=3$ )

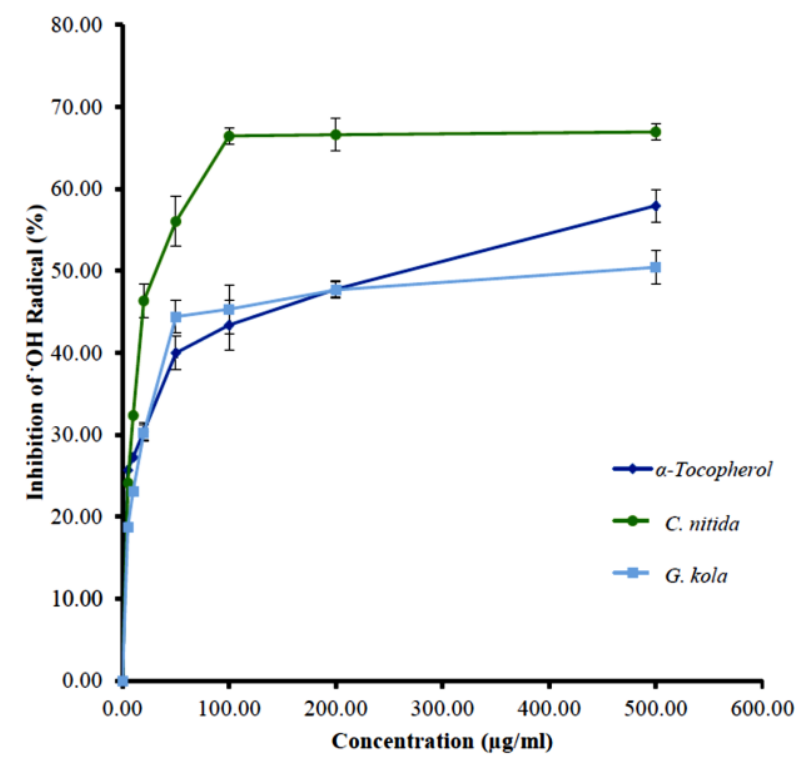

Fig. 2: Graph comparing Hydroxyl (.OH) antioxidant activity of different concentrations of $\alpha$ tocopherol and extracts of Garcinia kola and Cola nitida. Values are expressed as mean \pm SEM, n $=3$ )

Figure 3 shows the Garcinia kola and Cola nitida extracts which inhibited the formation of reduced NBT in a dose-related manner. $C$. nitida showed the maximal 
$\mathrm{O}_{2}-$ anion inhibitory activity of $86.68 \pm 2.10 \%$ at the concentration of $250 \mu \mathrm{g} / \mathrm{ml}$, compared to rutin $(96.03 \pm 2.2 \%$, at $250 \mu \mathrm{g} / \mathrm{ml})$. The $\mathrm{O}_{2}-$ scavenging effect of the extracts could culminate in the prevention of $\mathrm{OH}$ radical formation since $\mathrm{O}_{2}{ }^{-}$and $\mathrm{H}_{2} \mathrm{O}_{2}$ are required for $\mathrm{OH}$ radical generation.

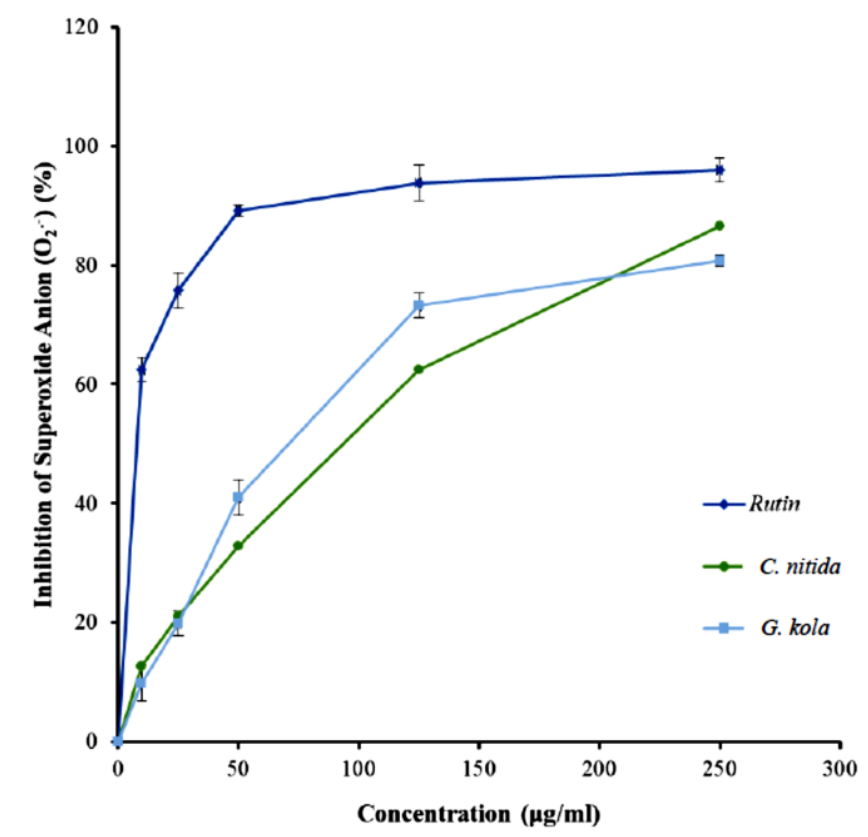

Fig. 3: Graph comparing superoxide anion $\left(\mathrm{O}_{2}-\right)$ inhibition of different concentrations of rutin and extracts of Garcinia kola and Cola nitida (values are mean $\pm \mathrm{SEM}, \mathrm{n}=3$ )

\section{Discussion}

The involvement of bacteria in urinary tract infection is of great concern. Female patients were only participant involved in this study because they are considered to be more predisposed to urinary tract infections. Studies have shown Escherichia coli and Staphylococcus saprophyticus as mostly implicated in urinary tract infection (Nicolle 2008). However, this study revealed the presence of Escherichia coli as the highest occurring bacteria with $14(29.17 \%)$, while Proteus vulgaris as the lowest with 4 $(8.33 \%)$ which agrees with Mansour et al. (2009). The presence of these bacteria could possibly be because of poor sanitary hygiene.

The findings from this study revealed the presence of alkaloids, saponins, tannins, flavonoids, glycoside, protein and the absent of terpenoids and resin in the extracts of Garcinia kola and Cola nitida in the methanol, ethanol and aqueous used as solvent as agreed with work done on $C$. nitida and G. kola by Omwirhiren et al. (2016). Studies have shown that the various solvents influence the nature of compounds extracted and their bioactivities (Arunkumar and Muthuselvam 2009, Seanego 2012). However, methanol extracts appear to be most potent and promising as shown by its high 
inhibitory activity against the clinical isolates. This could be attributed to the high presence of some of the polyphenolic compound identified (total flavonoids content of $25.63 \pm 1.60$ and $25.10 \pm 1.85 \mathrm{mg}$ rutin equivalents/g dry weight of $G$. kola and $C$. nitida respectively). These results clearly show that the solvent influences the extractability of the phenolic compounds. The phenolic extracts of plants are always a mixture of different classes of phenols, which are selectively soluble in the solvents. This finding is in conformity with previous studies by Ukaoma et al. (2013) and Alaje et al. (2014). The presence of these secondary metabolites is known to have therapeutic activity against several diseases and therefore could suggest the basis for their traditional use for the treatment of various illness (Yousuf et al. 2012) including urinary tract infections. Earlier studies have reported that flavonoids have antibacterial property as they have the capability to associate with soluble proteins and bacterial cell walls (Doss et al. 2011).

The evaluation of the antibacterial properties and the effect of mixture of extracts on bacterial isolates showed that they all possess antibacterial properties. The antibacterial activity was seen at varying concentrations indicating that the plant extract had broad antibacterial spectrum (Bankole 1992). Presence of alkaloids and flavonoids in G. kola and $C$. nitida has been observed to be responsible for its antibacterial property. However, the data obtained showed that the inhibitory effects of these plant extracts on the various bacterial isolates were dose dependent. This observation agrees with the findings of Agbaje et al. (2006) and Akinnibosun et al. (2009). The methanol extract of $G$. kola was most active against E. coli, K. pneumoniae, P. vulgaris, S. aureus, and $P$. aeruginosa with zones of inhibition ranging from $23.00 \mathrm{~mm}$ to $13.00 \mathrm{~mm}$. The ethanol extract of $G$. kola extract was active against E. coli, K. pneumoniae, $P$. vulgaris, $S$. aureus, and $P$. aeruginosa with zones of inhibition ranging from $22.66 \mathrm{~mm}$ to $12.66 \mathrm{~mm}$. While the aqueous $G$. kola was active against $P$. vulgaris, E. coli, $K$. pneumoniae, $P$. aeruginosa with zones of inhibition ranging from $17.00 \mathrm{~mm}$ to 12.33 $\mathrm{mm}$ and showed no zone of inhibition to $S$. aureus. This result is similar to the work of Adegboye et al. (2008), who showed that the crude extract of G. kola exhibited antibacterial activities in vitro against both Gram-positive and Gram-negative organisms. The antibacterial properties of this plant could be attributed to the presence of tanins and flavonones. Studies have shown it to have good antibacterial, antifungal and antiviral properties (Terashima et al. 2002, Adesuyi et al. 2012). Other medicinal properties of the plant include its usage in the treatment of skin infections in Liberia and Congo Democratic Republic. The powdered bark of the plant is applied to malignant tumors and cancers, whereas the plants latex is taken internally for gonorrhea and externally to seal new wounds and prevent sepsis (Adesuyi et al.2012). In Nigeria, a cold-water extract of the roots and bark with salt are administered to cases of bronchial asthma or cough and vomiting (Adesuyi et al. 2012).

Methanol extract of $C$. nitida was most active against $K$. pneumonia, E. coli, $S$. aureus, $P$. vulgaris, and $P$. aeruginosa with zones of inhibition ranging from 21.33 $\mathrm{mm}$ to $11.33 \mathrm{~mm}$. Ethanol $C$. nitida extract was active against $K$. pneumoniae, E. coli, $S$. aureus, $P$. vulgaris, $P$. aeruginosa with zones of inhibition ranging from $19.66 \mathrm{~mm}$ to $12.00 \mathrm{~mm}$. While the aqueous $C$. nitida was active against $E$. coli, P. vulgaris with 
zones of inhibition ranging from $16.66 \mathrm{~mm}$ to $10.66 \mathrm{~mm}$ and showed no zone of inhibition to $S$. aureus, $P$. aeruginosa and $K$. pneumoniae.

The mixture of the extracts produced greater zones of inhibition on the bacterial isolates than the zones of inhibition produced by $G$. kola and $C$. nitida when used separately. The effect of mixture of plant extracts on the bacterial isolates was seen with methanol extract and least with aqueous extract. The methanol mixture of extracts was observed to be most active against $P$. vulgaris, E. coli, $K$. pneumoniae, $S$. aureus, and $P$. aeruginosa with zones of inhibition ranging from $25.66 \mathrm{~mm}$ to $12.00 \mathrm{~mm}$. The ethanol mixture of extracts was seen to be active against E. coli, P. vulgaris, $K$. pneumoniae, $S$. aureus, and $P$. aeruginosa with zones of inhibition ranging from 25.66 $\mathrm{mm}$ to $12.33 \mathrm{~mm}$. While the aqueous mixture of both plants was also observed to be active against $P$. vulgaris, E. coli, $K$. pneumoniae, $P$. aeruginosa with zones of inhibition ranging from $20.00 \mathrm{~mm}$ to $11.66 \mathrm{~mm}$ and showed no zone of inhibition to $S$. aureus. With this result, the effect of the mixture of the extracts showed greater antibacterial activity against the bacterial isolates when favourably compared with the standard antibiotic. Although, no studies have shown this, that of Solenostemon monostachyus and Ocimum gratissimum (Chukwura and Iheukwumere, 2012) results showed they have greater inhibitory effect as G. kola and C. nitida extract mixture.

The MIC of the extracts against the bacteria was also determined varying between concentration of $31.25 \mathrm{mg} / \mathrm{ml}$ to $500 \mathrm{mg} / \mathrm{ml}$ for G. kola extract, $C$. nitida extract and the mixture of both extracts, respectively. The results of MIC showed that the mixture of extracts is more potent against the bacterial isolates even at low concentrations. The broad spectrum of activity displayed by the extracts in this study appears to justify and explain the basis for their uses in traditional medicine, possibly as a remedy to the emergence of drug-resistant strains caused by inappropriate use of orthodox antibiotics.

Garcinia kola and Cola nitida extracts showed significant dose-dependent DPPH radical scavenging capacity. Garcinia kola appears to be more efficient, inhibiting $92.36 \pm 1.31 \%$ of DPPH at a concentration of $125 \mu \mathrm{g} / \mathrm{ml}$ compared to ascorbic acid which inhibited $94.18 \pm 3.22 \%$ at the same concentration as proven by Okoko (2009). Garcinia kola and Cola nitida extracts scavenged $\mathrm{OH}$ radical in a concentration dependent manner. The two extracts inhibited 2-deoxyribose degradation above $30 \%$ with maximal inhibition of $76.7 \pm 1.4 \%$ at concentration of $500 \mu \mathrm{g} / \mathrm{ml}$. The scavenging ability of the extracts was significant at all tested concentrations. The high radical scavenging activity of Garcinia kola and Cola nitida seems to be directly correlated with its total phenolic content as it may play an important role in their antioxidative effect. $C$. nitida extract was also found to be powerful quencher of $\mathrm{OH}$ radical thereby preventing the propagation of lipid peroxidation. At high concentrations of both extracts lower activities were observed. Garcinia kola and Cola nitida extracts which inhibited the formation of reduced NBT in a dose-related manner. $C$. nitida showed the maximal $\mathrm{O}_{2}-$ anion inhibitory activity of $86.68 \pm 2.10 \%$ at the concentration of 250 $\mu \mathrm{g} / \mathrm{ml}$, compared to rutin $(96.03 \pm 2.2 \%$, at $250 \mu \mathrm{g} / \mathrm{ml})$. The $\mathrm{O}_{2}-$ scavenging effect of the extracts could culminate in the prevention of $\mathrm{OH}$ radical formation since $\mathrm{O}_{2}{ }^{-}$and $\mathrm{H}_{2} \mathrm{O}_{2}$ are required for $\mathrm{OH}$ radical generation. The observed ability of the extracts to scavenge or inhibit $\mathrm{HO}^{\cdot}$ radical indicated that the extracts could significantly inhibit 
lipid peroxidation. This corroborates the studies of Farshori et al. (2013) and Olatunde et al. (2004) who reported that $G$. kola and $C$. nitida contains natural antioxidants.

The $\mathrm{IC}_{50}$ is the concentration of the extracts that inhibited $50 \%$ of the free radicals and lipid peroxidation which was used to determine the potency of the extracts. The lower the $\mathrm{IC}_{50}$ value the higher the extract potency. The plant extracts were efficient inhibitors of different free radicals compared to standard antioxidants. G. kola appears to be more efficient in inhibiting DPPH radical $(9.6 \pm 1.0 \mu \mathrm{g} / \mathrm{ml})$, Superoxide anion $(64.6 \pm 1.5 \mu \mathrm{g} / \mathrm{ml})$ and lipid peroxidation $(282.9 \pm 9.3 \mu \mathrm{g} / \mathrm{ml})$ while $C$. nitida extract is a better inhibitor of Hydroxyl radical $(46.6 \pm 2.5 \mu \mathrm{g} / \mathrm{ml})$. $\mathrm{IC}_{50}$ was calculated as the amount of antioxidant present in the sample necessary to decrease the initial DPPH concentration by $50 \%$. The lower the $\mathrm{IC}_{50}$ value the higher is the antioxidant activity. The observed antibacterial property of these seeds could therefore be linked to the presence of the phenolic compounds as they have previously been found to be main contributors of antioxidant activity and are also responsible for anti-inflammatory, antiviral, anticancerous and antimicrobial activities (Yang et al. 2013).

\section{Conclusions}

The present study revealed the presence of phytochemicals in G. kola and C. nitida which exhibited promising antimicrobial activity against a broad spectrum of bacterial isolates. Another striking finding was that the extracts showed free radical scavenging potential properties against the synthetic oxidative molecules and varying degrees of antibacterial activity on the bacteria isolated, with the methanol extract demonstrating the most effective activity against all the isolate at all concentrations. This therefore reaffirms the ethno-pharmacological importance of G. kola and C. nitida and could serve as the basis for advanced studies in the development of drugs against infectious diseases. This would also prove useful especially due to the alarming rate of drug resistance which is posing a threat and a major challenge in treatment of infectious diseases. Apart from performing synergistic studies to evaluate the performance of $G$. kola and $C$. nitida when combined with orthodox medicine, there is also a need to determine the toxicity of the plant extracts which in our findings will be a prelude to initiating clinical trials in subsequent drug development.

\section{Acknowledgments}

Two anonymous reviewers are acknowledged for valuable comments on the initial draft of the manuscript.

\section{References}

Adegboye MF, Akinpelu DA, Okoh A. 2008. The bioactive and phytochemical properties of Garcinia kola (Heckel) seed extract on some pathogens. African Journal of Biotechnology 7 (21): 3934-3938.

Adesuyi AO, Elumm IK, Adaramola FB, Nwokocha AGM. 2012. Nutritional and Phytochemical Screening of Garcinia kola. Advanced Journal of Food Science and Technology 4(1): 9-14. 
Agbaje EO, Ogunsanya T, Aiwerioba OIR. 2006. Conventional use of honey as antibacterial agent. Annals of African Medicine 5(2): 78-81.

Agbo AG, Ngogang YJ. 2005. Toxicity of herbal preparations. Cameroon Journal of Ethnobotanical 1(1): 23-28.

Agbo AG, Oben EO, Ngogang YJ. 2005. Haematinic activity of hibiscus cannbinnus. African Journal of Biotechnology 2(4): 833-837.

Ajayi IA, Jonathan SG, Adewuyi A, Oderinde RA. 2008. Antimicrobial screening of essential oil of some herbal plants from Western Nigeria. World Applied Sciences Journal 3(1): 79-81.

Akinnibosun HA, Akinnibosun FI, Adieme BC. 2009. Biotherapeutic potential of aqueous and ethanolic extracts of Solenostemon monostachyus (P. Beauv.) Brig. leaves on some vegetative Gram-negative bacteria. Biological and Environmental Sciences Journal for the Tropics 6(3): 33-37.

Akoachere JF, Ndip RN, Chenwi EB. 2002. Antibacterial Effect of Zingiber officinale and Garcinia kola on respiratory Tract pathogens. East African Medical Journal 79: 588-592.

Alade PI, Irobi ON. 1993. Antimicrobial activities of crude extracts of Acalypha wilkesiana. Journal of Ethnopharmacology 39: 1-9.

Alaje DO, Owolabi KT, Olakunle TP, Oluoti OJ, Adetuberu IA. 2014. Nutritional, Minerals and Phytochemicals composition of Garcinia cola [Bitter cola] and Aframomum melegueta (Alligator pepper) IOSR Journal of Environmental Science, Toxicology and Food Technology 8(1):86-91.

Amalu PC, Chukwuezi FO, Ugwu OPC. 2014. Antimicrobial Effects of Bitter Kola (Garcinia kola) Nut on Staphylococcus Aureus, Escherichia coli and Candida albicans. Journal of Dental and Medical Sciences (IOSR-JDMS) 13(4): 29-32.

Arekemase MO, Aliyu MB, Kayode RMO, Ajiboye AE, Ajijolakewu AK. 2012. Antimicrobial Effects of Garcinia Kola (Bitter Kola) on Some Selected Pathogens from University of Ilorin Teaching Hospital Ilorin, Nigeria" Journal of Asian Scientific Research 2(4): 159-169.

Arunkumar S, Muthuselvam M. 2009. Analysis of phytochemical constituents and antimicrobial Activities of Aloe vera against Clinical Pathogens. World Journal of Agricultural Sciences 5(5): $572-$ 576.

Atata R, Sani A, Ajewole SM. 2003. Effect of stem bark extracts of Enantia chlranta on some clinical isolates. Biokemistri 15(2): 84-92.

Atawodi SE, Mende P, Pfundstein B, Preussmann R, Spiegelhalder B. (2005). Nitrosatable amines and nitrosamide formation in natural stimulants: Cola acuminate. C. nitida and Garcinia kola. Food and Chemical Toxicology 33: 625-630.

Bankole AA. 1992. The antibacterial activity of the crude seed extracts of three plants used in Nigerian ethnomedicine. University of Benin, Benin City, p. 45.

Beauchamp C, Fridovich I. 1971. Superoxide dismutase: Improved assay and an assay applicable to acrylamide gels. Analytical Biochemistry 44: 276-287.

Chabot S, Bel-Rhlid R, Chenevert R, Piche Y. 2002. Hyphal growth promotion in vitro of the VA mycorrhizal fungus, Gigaspora margarita Becker and Hall, by the activity of structurally specific flavonoid compounds under CO2-enriched conditions. New Phytologist 12: 461-467.

Chao-Hsun, Y, Yu-Chun H, Yu-fen C, Ming-Hsiang, C. 2010. Foam properties, detergent abilities and longterm preservative efficacy of the saponins from Sapindus Mukorossi. Journal of Food Drug Analysis 18: 155-160.

Chen K, Shi Q, Kashiwada Y, Zhang DC, Hu CQ, Jin JQ, Nozaki HRE, Kilkuskie T, Cheng YC. 2002. Anti-AIDS agents. 6. salaspermic acid, an anti-HIV principle from Tripterygium wilfordii, and the structure-activity correlation with its related compounds. Journal of Natural Products 55: 340-346.

Chessin M, DeBorde D, Zip FA. 2005. Antiviral proteins in higher plants. CRC Press, Inc., Boca Raton, Fla.

Chukwura EI, Iheukwumere IA. 2012. Determination of synergistic effect and activity index of Solenostemon monostachyus and Ocimum gratissimum on selected bacteria. Nigerian Journal of Microbiology 26: 2492-2498.

CLSI. 2015. Clinical and Laboratory Standards Institute, Performance Standards for Antimicrobial Susceptibility Testing; Twenty-Fifth Informational Supplement CLSI document M100-S25 35: 3.

Cowan MM. 2009. Plant products as antimicrobial agents. Clinical Microbiology Reviews 12: 564-582.

Dalziel JM. 2008. The useful plants of West Tropical Africa. Crown Agents for the Colonies, London 4548.

Ruhuna Journal of Science

Vol 11 (2): 98-117, December 2020 
Doss A, Parivuguna V, VijayaSanthi M, Sruthi S. 2011. Antibacterial and preliminary phytochemical analysis of Medicago sativa L. against some microbial pathogens. Indian Journal of Science and Technology 4(5): 550-552.

El-Mahmood AM, Doughari JH, Chanji FJ. 2008. In vitro antibacterial activities of crude extracts of Nauclea latifolia and Daniella oliveri. Scientific Research and Essays 3(3): 102-105.

Ezeigbo OR, Ejike EN, Nwachukwu I, Ejike BU. 2016. Comparative Antibacterial Activity of Methanolic, Ethanolic and Aqueous Extract of Garcinia kola (Bitter kola) and Cola nitida (Kola nut). International Journal of Plant Research 6(3): 53-56.

Fabiola BH, Tania U, Benedito, PDF, Diogenes AGC, Jose AM, Celso VN. 2003. Effect of essential oil of Ocimum gratissimum on the Trypanosomatid. Herpetomonas samuelpessoai. Protozoologica 42: 269-276.

Farshori NN, Al-Oquail MM, Al-Shedde SS, Siddequi MA. Rauf A. 2013. Antimicrobial potentiality of polyalthia longifolia seed oil against Multi Drug Resistant (MDR) strains of bacteria and fungus of clinical origin. African Journal of Microbiology Research 19: 1977-1982.

Gabriel A, Agbor DK, Julius EO. 2007. Medicinal plants can be good sources of antioxidants: case study in Cameroon. Pakistan Journal of Biological Sciences 10(4): 537-544.

Giusti MM, Wrolstad RE. 2001. Characterisation and measurement of anthocyanins by UV-visible spectroscopy. In: R. E. Wrolstad (Ed.). Current Protocols in Food Analytical Chemistry. New York: John Wiley and Sons. pp 45-65.

Green RJ. 2004. Antioxidant Activity of Peanut Plant Tissues. Masters' Thesis. North Carolina State University. United States of America.

Grieve M. 2001. Kola nuts (www.botanical.com).

Gyamfi MA, Yonamine M, Aniya Y. (1999). Free-radical scavenging action of medicinal herbs from Ghana: Thonningia sanguine on experimentally-induced liver injuries. General Pharmacology 32: 661-667.

Halliwell B, Gutteridge JMC, Aruoma OI. 1987. The deoxyribose method: simple 'test-tube' assay for determination of rate constants for reactions of hydroxyl radicals. Analytical Biochemistry 165: 215219.

Harborne JB. 1984. Phytochemical Methods: A Guide to Modern Technique of Plant Analysis, $2^{\text {nd }}$ eds. London: Chapman and Hall, London. pp 271.

Iwu MW, Duncan AR, Okunji CO. 2009. New Antimicrobials of plant Origin. In: Janick J. (ed.) Perspective on New Crops and New Uses. Alexandria, VA: pp. 459-462.

Jonathan SG, Fasidi IO. 2003. Antimicrobial activities of Lycoperdon pusilum (Bat.Ex.) and Lycoperdon giganteum (Pers.) Nigerian edible macrofungi. African Journal of Biomedical Research 6: 88-90.

Jonathan SG, Fasidi IO. 2005. Antimicrobial activities of some selected Nigerian mushrooms. African Journal of Biomedical Sciences 8(2): 83-87.

Jonathan G, Ohimain E, Kigigha L. 2007. Antagonistic effects of extracts of some Nigerian higher fungi against selected microorganisms. American-Eurasian Journal of Agricultural Environmental Sciences 2(4): 364- 368.

Kanomal AI, Muhammad I, Abdullahi S, Shehu K, Maishanu HM, Isah AD. 2014. Journal of Biology Agriculture and Healthcare 4(3) ISSN 2224-3208.

Keay RWJ, Onochie CFA, Stanfield DP. 2014. Nigerian Trees. Vol. 1 Department of Forest Research, Ibadan, Nigeria pp 51-54.

Kuete V, Ngameni B, Fotso-Simo CC, Kengap-Tankeu R, Tchaleu-Ngadjui B, Meyer JJ, Lall N, Kuiate JR. 2008. Antimicrobial activity of the crude extracts and compounds from Ficus chlamydocarpa and Ficus cordata. Journal of Ethnopharmacology 120: 17-24.

Kumaran A, Karunakaran J. 2006. In vitro antioxidant activities of methanol extracts of five Phyllanthus species from India. LWT-Food Science Technology 40: 344-352.

Maiyo ZC, Ngure RM, Matasyoh JC, Chepkorir R. 2010. Phytochemical constituents and antimicrobial activity of leaf extracts of three Amaranthus plant species. African Journal Biotechnology 9(21): 31783182.

Makkar HP, Bluemmel M, Borowy NK, Becker K. 1993. Gravimetric determination of tannins and their correlations with chemical and protein precipitation methods. Journal of the Science and Food Agriculture 61: 161-165. 
Mansour A, Manijeh M, Zohreh P. 2009. Study of bacteria isolated from urinary tract infection and determination of their susceptibility to antibiotics. Journal of Microbiology 2(3): 118-123.

Martinez AC, Marcelo EL, Marco AO, Moacyr M. 2001. Differential responses of superoxide dismutase in freezing resistant Solanum curtibolum and freezing sensitive Solanum tuberosum subjected to oxidative and water stress. Plant Science 160: 505-515.

NCCLS. 2010. National Committee for Clinical Laboratory Standards, Performance Standards for Antimicrobial Disk Susceptibility Tests: Approved Standard M2-A7. National Committee for Clinical Laboratory Standards. Wayne; Pennsylvania, United States of America.

Nicolle LE. 2008. Uncomplicated urinary tract infection in adults including uncomplicated pyelonephritis. Urologic Clinics of North America 35(1): 1-12.

Nweze EI, Onyishi MC. 2010. In vitro Antimicrobial Activity of ethanolic and methanolic extracts of Xylopia aethiopica and its combination with disc antibiotics against Clinical isolates of Bacteria and Fungi. Journal of Rural and Tropical Public Health 9: 1-6.

Okoko T. 2009. Chromatographic characterization, invitro antioxidant and free radical scavenging activities of Garcinia kola seeds. African Journal of Biotechnology 8: 7133-7137.

Olatunde FE, Hansen M, Rain-Haren P, Dragsted LO. (2004). Commonly consumed and naturally occurring dietary substances affect bio markers of oxidative stress and DNA damage in healthy rats. Food and Toxicology 42(8): 1315-1322.

Omwirhiren EM, James SA, Asefon OA. 2016. The phytochemical properties and antimicrobial potentials of aqueous and methanolic seed extract of Cola nitida (vent.) and Cola acuminate (Beauvoir) grown in South West, Nigeria. Saudi Journal of Medical and Pharmaceutical Sciences 2(12): 354-363.

Opeke LK. 2012. Tropical Tree Crops. Spectrum books Ltd. Ibadan, Nigeria.

Pudhom N, Thakur AR, Chaudhuri SR. 2007. Characterization of bacterial strains isolated through microbial profiling of urine samples. Journal of Biological Science 7(1): 44-51.

Rabe T, Vanstoden J. 2000. Isolation of an antimicrobial quiterpenoid from Warbugie salutaris. Journal of Pharmacology 93: 171-174.

Seanego CL. 2012. Phytochemical analysis and bioactivity of Garcinia kola (Heckel) seeds on selected bacterial pathogens. Unpublished M.Sc. (Microbiology) Thesis, University of Forte Hare.

Sofowora A. 1993. Medicinal plants and traditional medicine in Africa. Spectrum Books Ltd, Ibadan, Nigeria pp 289-294.

Terashima K, Takaya Y, Niwa M. 2002. Powerful antioxidative agents based on garcinoic acid from Garcinia kola. Bioorganic and Medicinal Chemistry 10(5): 1619-1625.

Trease GE, Evans WC. 2001. A TextBook of Pharmacognosy, $14^{\text {th }}$ Edn. W.B. Saunders Company Ltd. London; pp 193-201, 232-233, 249-252.

Ukaoma AA, Ukaoma VO, Okechukwu RI, Iwuagwu, M. 2013. Phytochemical screening and antibacterial properties of Garcinia kola. The Journal of Phytopharmacology 2(3): 34-38.

Velioglu YS, Mazza G, Gao L, Oomah BD. 1998. Antioxidant activity and total phenolics in selected fruits, vegetables, and grain products. Journal of Agricultural and Food Chemistry 46: 4113-4117.

WHO. 2000. World Health Organization, Expert Committee on medicinal importance of native plants. Technical report series. WHO-Geneva.

Wolfe K, Xianzhong W, Rui HL. 2003. Antioxidant activity of apple peels. Journal of Agricultural and Food Chemistry 51: 609-614.

Yang C, Chang H, Lin H, Chuang L. 2013. Evaluation of antioxidant and antimicrobial activities from 28 Chinese herbal medicines. Journal of Pharmacognosy and Phytochemistry 2(1): 294-305.

Yousuf M, Aslam K, Wani BA, Aslam N, Dar NA, Nawchoo IA. 2012. In vitro antibacterial activity and phytochemical studies of methanolic extract of leaves of Hypericum perforatum L. growing wild in Kashmir Himalaya. Asian Journal of Plant Science and Research 2(4): 414-420.

Zgoda JR, Porter JA. 2001. Convenient microdilution methods for screening natural products against bacteria and fungi. Pharmaceutical Biology 39: 221-225. 